\title{
PEMANFAATAN SUMBER ENERGI TERBARUKAN MELALUI PEMBUATAN PENGERING HIBRID SURYA-BIOMASSA PADA PENGERINGAN BIJ KOPI
}

\author{
Agoeng H Raharjo, Bambang Puguh, Hani Aprianti Solihah \\ Departemen Teknik Konversi Energi, Politeknik Negeri Bandung
}

\begin{abstract}
ABSTRAK
Indonesia merupakan negara tropis dengan kelimpahan sumber energi terbarukan berupa sinar matahari dan biomassa yang melimpah. Kedua jenis sumber energi terbarukan tersebut mulai digunakan dan dikembangan sebagai energi alternatif di sektor pertanian dan perkebunan dalam hal teknologi pengeringan. Salah satu produk perkebunan yang memperhatikan penggunaan teknologi pengeringan adalah kopi. Pada sistem pengeringan konvensional, penghilangan kadar air pada biji kopi mengandalkan kontak langsung dengan sinar matahari yang mana cuaca dan lama pengeringan dapat menjadi kelemahan sistem pengeringan tersebut. Pada penelitian dilakukan pembuatan pengering kopi sistem hibrid dengan menggunakan kolektor surya dan tungku biomassa berkapasitas $2,5 \mathrm{~kg}$. Hasil pengujian didapatkan efisiensi pengering sebesar 7,4\%, sedangkan pengeringan konvensional sebesar $4,4 \%$.
\end{abstract}

Kata kunci : Kolektor Surya, Tungku Biomassa, Pengering, Hibrid, Efisiensi

\section{ABSTRACT}

Indonesia is a tropical country with an abundance of renewable energy sources such as sunlight and biomass. Both types of renewable energy sources are brought into the application and development as an alternative energy in agriculture and plantations in terms of drying technology. One of agriculture product that takes into the use of plantation drying technology is coffee beans. In conventional drying system, the removal of the water content in coffee beans rely on direct contact with sunlight where weather and drying period can be a drawback of the drying system. This research was conducted by construct a coffee dryer with solar-biomass hybrid dryer system, using solar collector and biomass furnaces with $2.5 \mathrm{~kg}$ of capacity. The result was obtained dryer efficiency at $7.4 \%$, whereas the conventional drying was $4.4 \%$.

Keywords: Collector Solar, Biomass Stoves, Dryer, Hybrid, Efficiency

\section{PENDAHULUAN}

Upaya konservasi energi yang dicanangkan pemerintah, bermuara pada pemanfaatan energi terbarukan. Posisi geografi Indonesia yang strategis tepat dilintasi katulistiwa, menjadikan sumber energi terbarukan berupa sinar matahari dan biomassa menjadi berlimpah. Kondisi tersebut menjadi peluang akan penggunaan dan pengembangan energi alternatif yang bersumber dari energi terbarukan. Salah satu teknologi yang memanfaatkan kedua sumber energi terbarukan tersebut adalah teknologi pengeringan. Indonesia sebagai negara agraris, memiliki potensi produk pertanian dan perkebunan yang sangat tinggi. Salah satu proses pengolahan dari hasil perkebunan, khususnya perkebunan kopi adalah tahapan pengeringan. Teknologi pengeringan seperti teknologi surya termal pada bidang perkebunan sudah banyak dikembangkan. Dalam pengolahan biji kopi, pengeringan merupakan salah satu tahapan dalam mengolah kopi menjadi bubuk kopi dengan proses kering (dry process) dan proses basah (wet process) (PPKI, 2004). Proses pengeringan adalah suatu metoda atau cara untuk mengeluarkan (menghilangkan) sebagian air dari suatu bagian pangan dengan cara menguapkan air tersebut dengan menggunakan energi panas (LIPTAN, 2001). Kombinasi temperatur dan lama pemanasan 
selama proses pengeringan pada komoditi biji bijian dilakukan untuk menghindari terjadinya kerusakan biji. Temperatur udara, kelembaban relatif udara, aliran udara, kadar air awal bahan dan kadar akhir bahan merupakan faktor yang mempengaruhi waktu atau lama pengeringan (Brooker, 1992).

Pengeringan dapat dilakukan dengan dua cara yaitu:

1. Pengeringan dengan sinar matahari (alami), dengan cara semua biji kopi diletakkan dilantai penjemuran secara merata.

2. Pengeringan dengan menggunakan mesin pengering.

Banyak produsen biji kopi di Indonesia, masih menggunakan teknik pengeringan sederhana yaitu dengan menjemur langsung produk di atas papan maupun tikar, dimana proses tersebut dipengaruhi oleh frekuensi curah hujan dan intensitas sinar matahari. Pemanfaatan kedua sumber energi dalam proses pengeringan dapat dilakukan dengan system pengeringan hibrid. Prinsip kerja pengering hibrid tersebut adalah dengan memanfaatkan energi panas matahari dengan menggunakan kolektor surya yang dikombinasikan dengan tungku biomassa guna mempercepat proses pengeringan. Zulfri dkk (2012) melakukan kajian eksperimental terhadap system pengering hybrid energisurya-biomassa terhadap pengeringan ikan yang mampu menghilangkan kadar air hingga $50 \%$ dari berat ikan segar dalam 18 jam pengeringan. Nawawi (2009) melakukan pengujian performansi sistem pemanasan pada alat pengering hibrid tipe lorong untuk pengeringan ikan samgeh dan menunjukkan rata-rata nilai efisiensi sistem tungku berada pada kisaran $13.92-15.33 \%$. Pada penelitian ini dilakukan pembuatan pengering hybrid suryabiomassa pada proses pengeringan biji kopi.

\section{METODOLOGI}

Pengering hibrid ini bekerja dengan memanfaatkan energi matahari dan biomassa sebagai tambahan energi panas (Gambar 1). Kolektor matahari bekerja dengan memanfaatkan radiasi dari cahaya matahari yang diserap oleh plat alumunium yang dicat hitam doff sebagai absorber. Perpindahan pada plat terjadi secara konduksi, panas yang diterima plat menyebar di sirkulasi udara dalam kolektor surya dan terjebak karena kaca. Maka udara yang keluar dari plat kolektor akan menjadi panas. Sesuai dengan sifat udara yang mengalir dari temperatur rendah ke temperatur tinggi. Udara panas akan masuk ke ruang pengering. Kolektor surya memanfaatkan efek rumah kaca. Panas terperangkap menyebabkan temperatur di dalam box kolektor meningkat. Udara panas dari ruang kolektor akan naik ke atas dan melewati objek pengeringan.

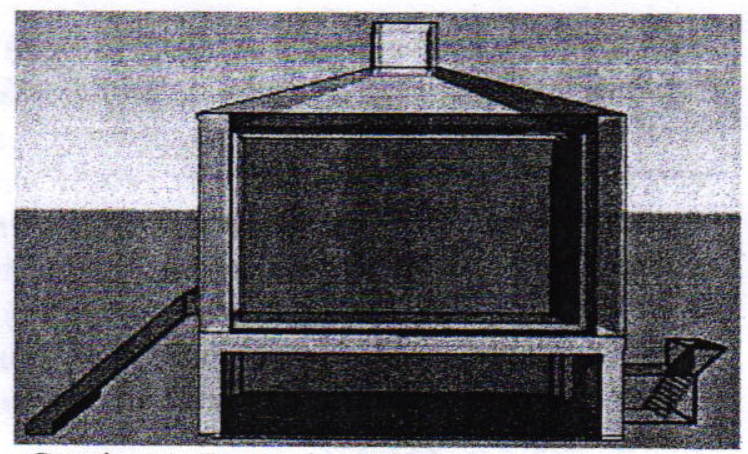

Gambar 1. Pengering Hibrid Solar-Biomassa

Sekam dibakar di tungku biomassa yang berfungsi sebagai sumber energi tambahan dan aliran panas hasil pembakaran sekam akan mengalir ke atas menuju ruang pengering. Namun terdapat saluran khusus dari udara panas hasil pembakaran. sehingga tidak terjadi kontak langsung antara udara panas hasil pembakaran dengan objek yang dikeringkan. Udara panas hasil pembakaran akan memanaskan ruangan pengering melalui saluran di dinding-dinding ruang pengering. Dan udara panas akan keluar melalui cerobong yang mempertemukan saluran di atas ruang pengering. Dengan adanya tungku biomassa ini diharapkan temperatur di ruang pengering akan meningkat dan mempercepat proses pengeringan.

Untuk mendapatkan karakteristik dari kolektor dan menghitung performansi menggunakan persamaan berikut (Moran Saphiro, 2006):

1. Persamaan Pengeringan

Kandungan air suatu bahan dapat dinyatakan dalam wet basis dan dry basis kandungan kelembaban air suatu bahan dalam wet basis menyatakan perbandingan masa air dalam bahan dengan masa total bahan. Sedangkan pada dry basis kandungan air di hitung dengan membagi masa air dalam bahan dengan masa keringnya saja. 


\section{Kadar Air}

Untuk menghitung kadar air berdasarkan bobot kering digunakan rumus :

$\mathrm{Ka}=\frac{w 1-w 2}{w 1} \times 100 \%$

\section{Massa Uap yang Diuapkan}

Untuk menghitung massa uap air biji kopi yang dikeringkan digunakan rumus :

Massa uap air biji kopi yang di keringkan = massa awal-massa akhir .

\section{Laju Pengeringan}

Untuk menghitung laju pengeringan menggunakan persamaan :

Laju Pengeringan $=\frac{m u a p}{t}$.

Keterangan :

$\mathrm{M}_{\text {uap }}$ = Massa uap air yang diuapkan (kg)

t $\quad$ Waktu pengeringan (jam)

\section{Energi Pemanasan}

Untuk menghitung energi pemanasan digunakan Persamaan 3 (JP. Holman : 1990)

Pemanasan terjadi yaitu pemanasan pada air yang terkandung pada bahan dan pemanasan pada bahan itu sendiri

$\mathrm{Q}_{\text {bahan }}=\mathrm{M}_{\text {bahan }} \times \mathrm{Cp}_{\text {bahan }} \times \Delta \mathrm{T}$.

Keterangan:

$\mathrm{M}_{\text {bahan }}=$ Massa bahan per waktu (kg/jam)

$\mathrm{Cp}_{\text {bahan }}=$ Spesific heat $\left(\mathrm{kJ} / \mathrm{kg}^{\circ} \mathrm{C}\right)$

$\Delta \mathrm{T}=$ Temperatur bahan - temperatur lingkungan $\left({ }^{\circ} \mathrm{C}\right)$

\section{Energi Penguapan}

Untuk menghitung energi penguapan dapat dihitung menggunakan persamaan :

$\mathrm{Q}_{\text {uap }}=\dot{\mathrm{m}}_{\text {uap }} \times \mathrm{hfg}$

Keterangan:

$\dot{\mathrm{m}}_{\text {uap }}$ : Air yang diuapkan (kg/jam)

hfg : Panas laten penguapan pada temperatur tertentu $(\mathrm{kJ} / \mathrm{kg})$

\section{Energi Pengeringan}

Untuk menghitung energi pengeringan dapat dihitung dengan menggunakan :
$\mathrm{Q}_{\text {pengeringan }}=\mathrm{Q}_{\text {bahan }}+\mathrm{Q}_{\text {uap }}$

\section{Energi yang diterima Kolektor}

Untuk menghitung energi yang diterima kolektor dapat menggunakan persamaan :

$Q_{\text {in }}=I_{k} \times A$

Keterangan:

$\mathrm{I}_{\mathrm{k}}$ : intensitas kumulatif $\left(\mathrm{Wh} / \mathrm{m}^{2}\right)$

A : Luas kolektor $\left(\mathrm{m}^{2}\right)$

\section{Energi Tungku}

Untuk menghitung energi pada tungku dapat menggunakan persamaan :

$\mathrm{Q}_{\text {tungku }}=\mathrm{M}_{\mathrm{bb}} \mathrm{x} \mathrm{NHV}$

\footnotetext{
Keterangan :

NHV = Net Heating Value Bahan

Bakar (kkal/kg)

$\mathrm{M}_{\mathrm{bb}}=$ Massa bahan bakar yang masuk (kg)

Energi Input
}

Untuk menghitung energi input dapat dihitung dengan menggunakan persamaan :

$Q_{\text {input }}=Q_{\text {sc }}+Q_{\text {tungku }}$

\section{Kesetimbangan Energi}

Untuk menghitung kesetimbangan energi pada alat pengering maka dapat menggunakan persamaan :

$\mathrm{Q}_{\text {in }}=\mathrm{Q}_{\text {pengeringan }}+\mathrm{Q}_{\text {uap }}$

\section{Efisiensi Pengering}

Efisiensi pengering dapat didefinisikan sebaagai perbandingan antara panas yang berguna dari kolektor ke fluida dengan energi yang diterima oleh sistem. Prinsip dasar untuk menghitung efisiensi kolektor adalah membandingkan energi pengeringan dengan energi yang diserap kolektor. Untuk menghitungnya dapat digunakan persamaan :

$\eta=\frac{\text { Qpengeringan }}{\text { Qsc }+ \text { Qtungku }} \times 100 \%$

\section{HASIL DAN PEMBAHASAN}

Pengujian kopi menggunakan alat pengering hibrid dengan massa awal 2500 gram dan massa akhir 2145 gram. Pengujian kopi menggunakan cara konvensional dengan massa awal 2500 gram dan massa akhir 2463 gram. 


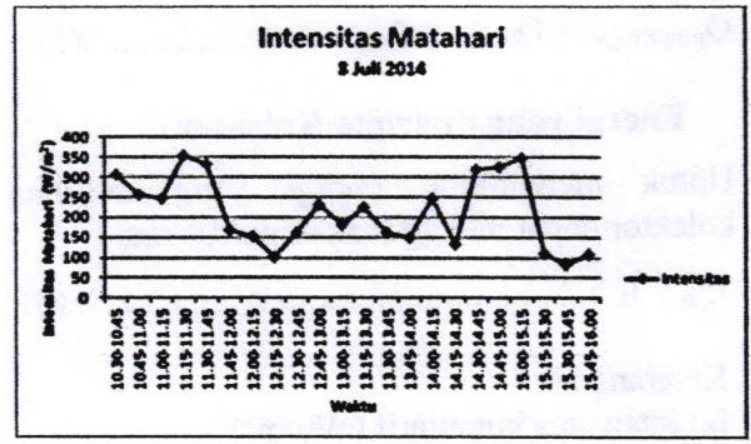

Gambar 2 Grafik Hubungan Waktu Terhadap Intensitas Matahari

Pada saat dilakukan pengujian alat, yaitu pengering sistem hibrid. Saat pengujian intensitas matahari tidak begitu baik. Intensitas matahari yang tidak begitu baik dapat dilihat pada Gambar 2 dari besar intensitas radiasi matahari yang tidak begitu besar dan berfluktuasi. Berdasarkan data pengamatan intensitas radiasi rata-rata adalah sebesar $214,23 \mathrm{~W} / \mathrm{m}^{2}$, dengan intensitas radiasi terbesar sebesar $354 \mathrm{~W} / \mathrm{m}^{2}$ pada pukul $11.15 \mathrm{WIB}$, dan intensitas radiasi terkecil sebesar $84 \mathrm{~W} / \mathrm{m}^{2}$ pada pukul 15.30 WIB.

Nilai intensitas radiasi matahari yang fluktuatif dan tidak begitu tinggi menyebabkan kenaikan temperatur pada plat, kaca, dan tunnel tidak begitu tinggi karena intensitas radiasi yang diserap oleh plat tidak maksimal. Gambar 3 menyajikan hubungan antara temperatur pada plat, kaca dan tunnel terhadap waktu. Semakin besar intensitas matahari, maka temperaturpada kolektor pun akan semakin tinggi. Temperatur tunnel yang tinggi, akan mempengaruhi temperatur ruang pengering.

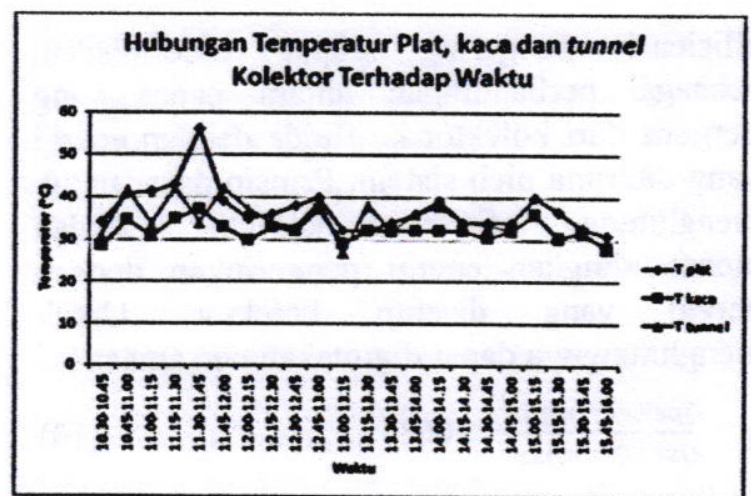

Gambar 3. Grafik Hubungan Temperatur Plat, Kaca dan Tunel Terhadap Intensitas Matahari

Semakin tinggi temperatur tunnel. Semakin banyak energi panas yang disuplai menuju ruang pengering. Suplai temperatur panas yang tinggi dan stabil dapat mempercepat proses pengeringan itu sendiri. Berdasarkan data temperatur tunnel rata-rata adalah sebesar $34,73^{\circ} \mathrm{C}$. Temperatur tunnel maksimal sebesar $42^{\circ} \mathrm{C}$ pada pukul 11.15 WIB dan temperatur tunnel minimal adalah sebesar $27^{\circ} \mathrm{C}$ pada pukul 13.00 WIB.

Selain temperatur tunnel, kaca dan plat, temperatur ruang juga diamati. Namun, karena sumber energi yang digunakan untuk memanaskan ruang berasal dari dua sumber panas. Maka, temperatur dari ruang pengering merupakan akumulasi dari panas tungku dan kolektor surya. Berdasarkan grafik tempertur ruang berfluktuasi. Dengan temperatur rata-rata sebesar $64,14^{\circ} \mathrm{C}$. Temperatur maksimal ruang yaitu sebesar $87^{\circ} \mathrm{C}$ dan temperatur ruang minimal sebesar $34,7^{\circ} \mathrm{C}$. Temperatur minimal terjadi pada pukul 10.30 , hal ini disebabkan karena pengering baru dioperasikan dan panas dalam ruang pengering belum stabil dan terkumulasi dengan baik. Grafik 4 menyajikan karakteristik temperatur ruang.

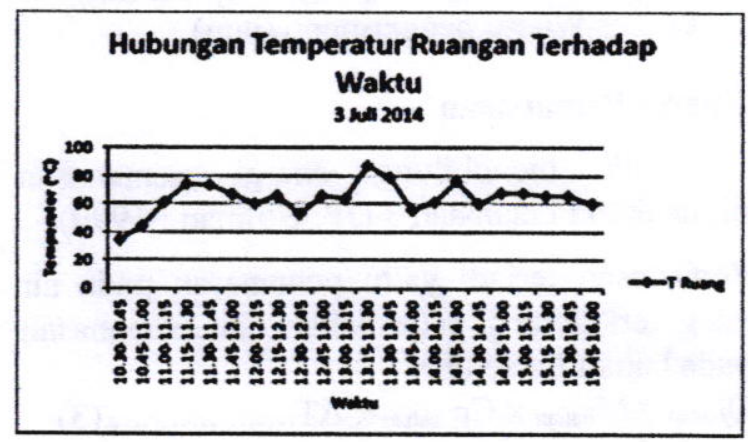

Gambar 4. Karakteristik temperatur ruangan

Untuk hubungan antara temperatur kopi terhadap waktu disajikan pada gambar 5 . Temperatur kopi akan dipengaruhi oleh temperatur ruangan. Berdasarkan data pengamatan temperatur kopi rata-rata adalah $47,9^{\circ} \mathrm{C}$, dengan temperatur kopi terendah sebesar $31,1^{\circ} \mathrm{C}$ dan temperatur kopi tertinggi sebesar $71^{\circ} \mathrm{C}$. Sama halnya dengan temperatur ruangan, pada saat baru dioperasikan temperatur kopi masih rendah dan beranjak naik, karena panas yang belum terakumulasi dan stabil. Tungku sendiri membutuhkan proses penyalaan yang membutuhkan waktu. Setting temperatur ruang pengering yang disarankan untuk proses pengeringan tahap I adalah sebesar $60^{\circ} \mathrm{C}-100^{\circ} \mathrm{C}$. Namun temperatur ruang pengering yang terlalu panas akan menyebabkan overheat. Laju pengeringan yang terlalu cepat akan case hardening atau pengerasan pada kulit luar produk. Maka 
temperatur rang pengering harus dijaga agar tidak melewati range tersebut.

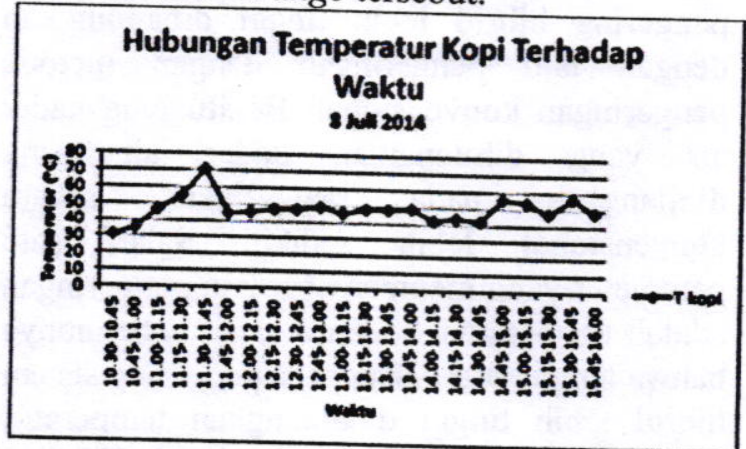

Gambar 5. Hubungan Temperatur Kopi Terhadap Waktu

Dari hasil pengujian didapatkan bahwa temperatur ruangan masih dapat dipenuhi walaupun dengan kondisi salah satu sumber energi, yaitu energi matahari tidak maksimal. Namun apabila dibandingkan, besar energi yang lebih dominan dalam proses pemanasan ruang pengering adalah energi yang berasal dari tungku biomassa. Perbandingan input kedua energi tersebut terdapat pada tabel 1 sebagai berikut :

Tabel.1 Perbandingan Energi Kolektor surya dan Tungku

\begin{tabular}{|c|c|}
\hline $\begin{array}{c}\text { Q Kolektor } \\
\text { Surya }\end{array}$ & Q Tungku \\
\hline $0,217 \mathrm{kWh}$ & $4,07 \mathrm{kWh}$ \\
\hline
\end{tabular}

Pada gambar 6 menunjukkan hubungan antara temperatur ruangan dan temperatur exhaust tungku terhadap waktu.

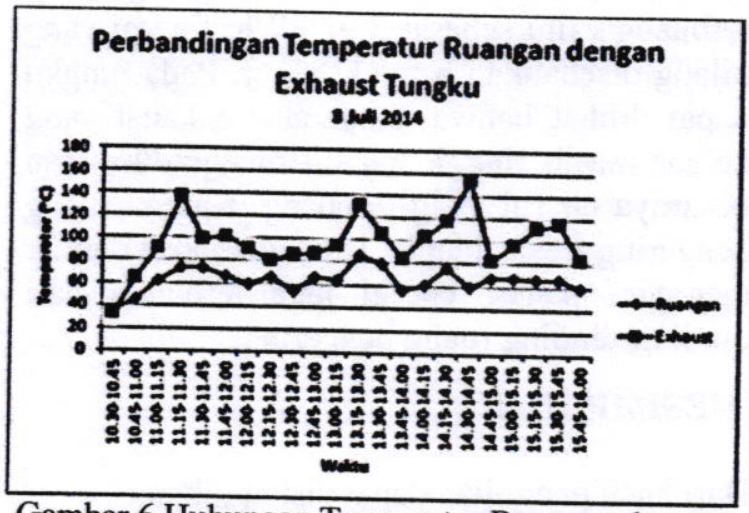

Gambar 6 Hubungan Temperatur Ruangan dengan Exhaust Tungku Terhadap Waktu

Karena temperatur ruangan adalah akumulasi panas dari kolektor surya dan tungku. Maka panas yang terdapat pada ruangan pengering tidak hanya dipengaruhi oleh tungku saja.
Namun dari grafik ini dapat dilihat penyerapan panas tungku oleh ruang pengering. Temperatur exhaust tungku yang tinggi mengindikasikan energi tungku tidak termanfaatkan dengan baik. Temperatur exhaust tungku tertinggi adalah sebesar $155^{\circ} \mathrm{C}$, dengan temperatur tungku terendah sebesar $32,5^{\circ} \mathrm{C}$ pada saat alat baru dioperasikan.

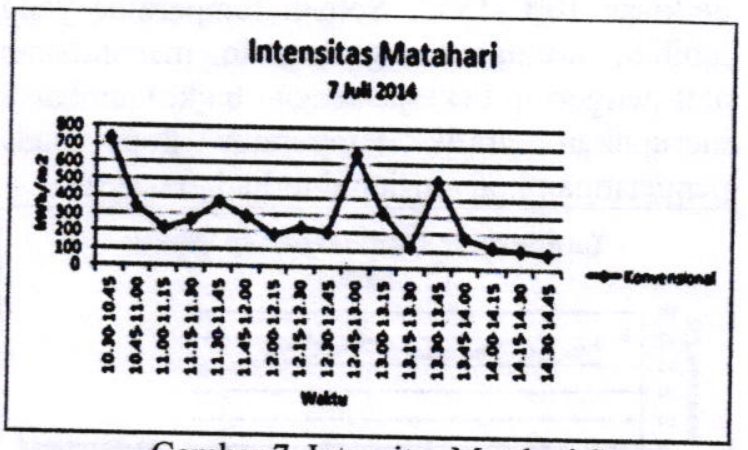

Gambar 7. Intensitas Matahari Saat Pengeringan Konvensional

Pengeringan menggunakan sistem pengeringan konvensional dan menggunakan alat pengering hibrid dibandingkan untuk mengetahui karakteristik dan efektifitasnya. Gambar 7 menyajikan intensitas matahari saat pengujian dengan metode konvensional. Pengujian dilakukan dengan menggunakan massa kopi yang sama, namun hari yang berbeda. Kadar air yang ingin dicapai adalah sebesar 30\% dengan kadar air asumsi awal sebesar 54\%. Pengeringan secara konvensional dilakukan pada hari cerah, tujuannya mengetahui efektifitas maksimal pengeringan secara konvensional pada kondisi cuaca yang maksimal. Namun jam operasi pada pengeringan konvensional lebih sebentar dikarenakan kendala cuaca pada sore hari.

Jam operasi pada saat pengujian alat pengering hibrid yaitu selama 5,5 jam, sedangkan pada pengeringan konvensional hanya $4 \mathrm{jam}$. Hal ini karena intensitas radiasi matahari yang kian mengecil dan cuaca gerimis yang tidak mendukung pada saat pengujian pengeringan secara konvensional. Pada grafik 6 dapat dilihat fluktuasi intensitas matahari pada saat pengeringan secara konvensional. Intensitas matahari terbesar yaitu sebesar $727 \mathrm{~W} / \mathrm{m}^{2}$, dan intensitas matahari terkecil yaitu sebesar 92 $\mathrm{W} / \mathrm{m}^{2}$. Intensitas matahari akan mempengaruhi energi yang diserap oleh kopi, dan akan mempengaruhi temperatur kopi juga. Semakin 
tinggi intensitas matahari maka akan semakin cepat proses penguapan.

Dilihat dari sisi temperatur, alat pengering kopi hibrid ini memiliki temperatur kopi ratarata sebesar $47,9^{\circ} \mathrm{C}$. Sedangkan pada pengeringan secara konvensional temperatur kopi rata-rata hanya sebesar $35,51^{\circ} \mathrm{C}$. Temperatur yang lebih tinggi akan menyebabkan proses pengeringan pada pengering hibrid lebih cepat. Selisih temperatur berkisar $10^{\circ} \mathrm{C}-15^{\circ} \mathrm{C}$. Selisih temperatur yang lebih besar dalam ruang pengering menandakan alat pengering bekerja dengan baik. Gambar 8 merupakan grafik temperatur kopi pada pengeringan konvensional terhadap waktu.

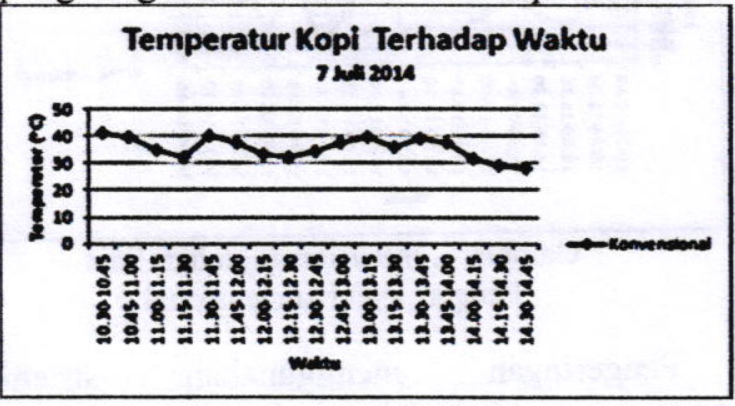

Gambar 8 Hubungan Temperatur Kopi Terhadap Waktu Pada Pengeringan Konvensional

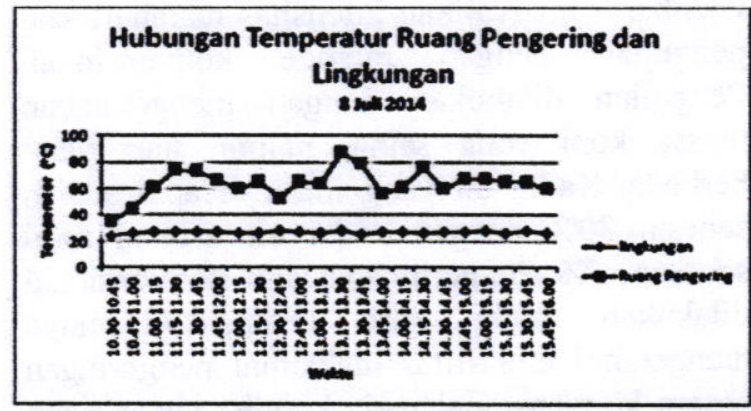

Gambar 9 Hubungan Temperatur Ruangan Pengering dan Lingkungan Terhadap Waktu

Gambar 9 menyajikan perbandingan antara temperatur lingkungan dengan temperatur di dalam ruang pengering. Terlihat pada grafik bahwa temperatur lingkungan cenderung stabil, sedangkan temperatur ruang pengering berfluktuasi. Perbedaan temperatur lingkungan dengan temperatur lingkungan mengindikasikan kinerja yang baik pada ruang pengering untuk mempercepat proses pengeringan. Tapi sebaliknya temperatur ruang pengering juga dijaga stabil. Namun untuk membuat temperatur ruangan pengering stabil dibutuhkan pengontrolan terhadap kedua sumber panas.
Berdasarkan hasil pengujian didapatkan bahwa laju pengeringan maupun efektifitas pada alat pengering hibrid lebih tinggi dibandingkan dengan laju pengeringan dengan metode pengeringan konvensional. Begitu juga kadar air yang dihilangkan, kadar air yang dihilangkan pada pengeringan secara konvensional lebih sedikit. Salah satu parameter yang mempercepat laju pengeringan adalah temperatur. Sudah dibahas sebelumnya bahwa temperatur bahan pada pengering sistem hibrid lebih tinggi dibandingkan temperatur bahan pada pengering konvensional. Tabel 2 menunjukkan perbandingan data pada saat pengujian dengan menggunakan pengeringan konvensional dan menggunakan alat pengering hibrid.

Tabel 2 Data Perbandingan Pengeringan Konvensional dan Pengering Hibrid

\begin{tabular}{|c|l|c|c|}
\hline \multirow{2}{*}{ No } & \multicolumn{1}{|c|}{ Parameter } & \multicolumn{2}{|c|}{ Metode } \\
\cline { 3 - 4 } & & Hybrid & Konvensional \\
\hline 1 & Massa Awal & 2500 gram & 2500 gram \\
\hline 2 & Massa Akhir & 2145 gram & 2463 gram \\
\hline 3 & Jam Operasi & 5,5 jam & 4 jam \\
\hline 4 & Laju Pengeringan & 64,55 gram/jam & 9,25 gram/jam \\
\hline 5 & $\begin{array}{l}\text { Kadar air yang } \\
\text { hilang }\end{array}$ & $14,20 \%$ & $1,48 \%$ \\
\hline 5 & Efisiensi & $7,04 \%$ & $4,40 \%$ \\
\hline
\end{tabular}

Energi yang diterima kolektor surya dan tungku biomassa tidak seluruhnya digunakan oleh alat pengering untuk mengeringkan kopi. Saat proses pengujian diketahui bahwa massa kopi yang masuk yaitu 2500 gram dengan energi input sebesar 4,287 kWh. Namun yang digunakan untuk mengeringkan kopi hanya sebesar $0,3174 \mathrm{kWh}$. Jadi besar energi yang terbuang yaitu sebesar 3,97 kWh. Energi yang hilang disebabkan banyak faktor. Pada tungku dapat dilihat bahwa temperatur exhaust yang keluar masih tinggi, hal ini mengindikasikan besarnya energi yang terbuang. Karena ruang pengering tidak dilapisi insulator (jaket) untuk meredam panas, energi juga terbuang dari dinding-dinding ruang pengering.

\section{KESIMPULAN}

Dari hasil pengujian dapat disimpulkan :

- Ruang pengering dari alat yang dibuat memiliki temperatur lebih tinggi $33,5^{\circ} \mathrm{C}$ dibandingkan temperatur lingkungan. Temperatur ruang yang lebih tinggi dibandingkan temperatur lingkungan akan mempercepat proses pengeringan. 
- Proses pengeringan dengan pengering hibrid, apabila dibandingkan dengan data proses pengeringan konvensional lebih cepat proses pengeringannya. Dalam waktu operasi 5,5 jam dengan kondisi terik matahari yang berfluktuasi dapat menghilangkan kadar air sebesar 14,2\%.

- Laju pengeringan pada pengering sistem hibrid lebih cepat dibandingkan dengan sistem pengeringan konvensial. Laju pengeringan hibrid sebesar 64,55 gram/jam, sedangkan konvensional sebesar 9,25 gram/jam

- Rugi-rugi pada kolektor surya berasal dari energi yang terbuang dari celah antara kolektor surya dan ruang pengering. Sedangkan rugi-rugi energi pada tungku disebabkan oleh energi tungku yang tidak seluruhnya diserap oleh ruang pengering. Hal tersebut dapat dilihat dari temperatur exhaust yang masih tinggi dengan rata-rata sebesar $98,05{ }^{\circ} \mathrm{C}$. Rugi-rugi juga timbul karena energi panas juga keluar dari dari dinding-dinding ruang pengering maupun dinding tungku.

- Efisiensi pengering sistem hibrid pada adalah 7,4 \%, sedangkan efisiensi pengering konvensional sebesar $4,4 \%$.

- Alat pengering kopi sistem hibrid lebih higienis dan lebih cepat waktu operasinya dalam proses pengeringan biji kopi dibandingkan dengan pengeringan secara konvensional.

\section{DAFTAR PUSTAKA}

Brooker, D.B., Bakker-Arkema, F.W. dan Hall, C.W., 1992, Drying and Storage of Grains and Oil Seed. $4^{\text {th }}$ edition, van Nostrad USA.

LIPTAN (Lembar Informasi Pertanian). 2001. Alat Pengering Surya Sederhana Yang Serbaguna

Moran, Micael J., dan Shapiro, Howard N. 2006. Fundamentals Of Engineering Thermodynamics 5th Edition. USA: John Wiley dan Sons

Nawawi, Ahmad. 2009. Sistem Pemanasan Pada Alat Pengering Hibrid Tipe Lorong Untuk Pengeringan Ikan Samgeh. Skripsi. Institut Pertanian Bogor.
Pusat Penelitian Kopi dan Kakao Indonesia (PPKKI). 2006. Pengolah Produk Primer dan Sekunder Kopi, Jember.

Zulfri, Muhammad, Ahmad Syuhada, hamdani. 2012. Kaji Eksperimental Sistem Pengering Hibrid Energi Surya-Biomassa untuk Pengering Ikan. Jurnal Teknik Mesin. Pascasarjana Universitas Syiah Kuala. ISSN 2302-0245. 